\title{
Economic Structure and Key Partnerships of Vilnius Jews from The Second Half of The 17th Century to The ENd of THe 18TH ${ }^{1}$
}

\author{
Darius Sakalauskas \\ (Vilnius University, Vilnius) \\ e-mail: darius.sakalauskas@yahoo.com
}

Keywords: structures, partnerships, patronages, Vilnius, Jewish community, early-modern economy, city, capital, money

Abstract: This article analyses the economic structure and partnerships of the Vilnius Jewish community from the second half of the 17th until the end of the 18th centuries. The article focuses on the economic partnerships and patronages formed by Jews in Vilnius. It also highlights the importance of the immediate hinterland for their business opportunities.

The Jewish community in Vilnius, the biggest in the Grand Duchy of Lithuania (GDL) since the 1700s, has not attracted similar historiographical attention ${ }^{2}$ for its economic history as some of the smaller communities in GDL. ${ }^{3}$ Out of the available works about the history of the Vilnius Jewish community, perhaps Israel Cohen ${ }^{4}$ provided the most comprehensive analyses of its economic situation. He had access to some of the communal documents, which gave interesting insights into daily economic life, communal provisions, and competition with the Christian artisans (although it could be argued this was slightly exaggerated). The competitive nature of the community's economic life was also the focus of extensive work done by Jurgita Verbickienè. ${ }^{5}$ However, as she mostly relied on legal documents and litigations, her work emphasized both the normative and competitive side of the Jews' economic life in Vilnius. Also, Vilnius was not the sole focus of her research, so her conclusions were applied to the whole of

1 This article was supported by a GEOP Research Fellowship at POLIN Museum of the History of Polish Jews and the Emanuel Ringelblum Jewish Historical Institute, within the POLIN Museum Global Education Outreach Program, funded by the William K. Bowes Jr. Foundation, Taube Philanthropies, and the Association of the Jewish Historical Institute of Poland. The statements made and views expressed herein, however, are solely the responsibility of the author.
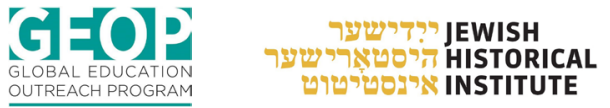

2 Although there is a substantial body of work on the community's history in general. See: Бершадский 1881; Бершадский 1883; Бершадский 1886, Klausner 1938; Cohen 2003; Tamulynas 1999; Blažytė 1999; Šiaučiūnaitè-Verbickienė 2009; Frick 2013.

3 Rosman 1991; Bardach 1990; Nadav 2008; Cieśla 2012; Cieśla 2013; Maciulevičius 2015; Teller 2016.

4 Cohen 2003.

5 Šiaučiūnaitė-Verbickienė 2009: 152-175. 
GDL. For those reasons we still lack a coherent picture of the economic life of Vilnius Jews, their partnerships, scale and geography of activity, the rationales and motives that determined day-to-day life. The over-dependence on Christian sources obviously harden the prospects of this type of analysis. However, as we will be able to use previously scarcely analysed economic management and ego documents, ${ }^{6}$ we will try to contribute to the above-mentioned issues. The focus of this article is the analysis of the key economic partnerships for Jews in Vilnius, their scale, and the importance of Jews in the larger area of the Vilnius economic hinterland. The chronology of the research coincides with the establishment and the growth of the Jewish community in Vilnius and the period of the city's history between the hardships during the mid-17th century until the last partition of GDL in 1795, when Vilnius was annexed by the Russian Empire.

\section{Jews in 17th and 18th-century Vilnius: Demographic trends and economic structure}

Vilnius emerged from the mid-17th century after the so-called Deluge (1655-1661) with significant casualties to the number of people, and devastation of property and equipment. ${ }^{7}$ It was a result of armed conflict, atrocities of the Russian forces perpetrated in the city, and a plague in the city that started in $1657 .{ }^{8}$ Even though it is hard to define the actual number of people in the city and its surroundings at various dates, the general consensus is that before the Deluge the number of people in Vilnius could have reached $25,000 .{ }^{9}$ The war and difficulties that came with it lowered this number by approximately 8,000 to 10,000 people. ${ }^{10}$ Rebuilding and re-establishing the city was difficult: houses were left empty and in ruins, a lack of people hindered the process of rebuilding, and capital was scarce for investment as savings were not really in the plans of the major economic agents ${ }^{11}$ and those that were established were most probably seized during the war. Additionally, inflationary and money debasement mechanisms ${ }^{12}$ in the middle to late 1600 s further aggravated the situation. It was not helped by the Northern War, a plague at the beginning of the 1700 s, and devastating fires in the mid1700 s. ${ }^{13}$ Therefore, normalization and a stable economic growth period came only in the later 1700 s.

The number of Jews living in Vilnius in the 17 th and 18 th centuries is a complicated matter due to the nature of the sources (tax records) and their deficiencies. Up until the $1764-1765$ census, ${ }^{14}$ the dynamics of the Jewish population is rather fragmentary.

${ }^{6}$ Like inventories, contracts, tax registries, letters and others.

7 Łowmiańska 1929; Meilus 2001.

8 Meilus 2001: 283.

9 Łowmiańska 1929: 71; Paknys 2006: 18; Wilnianie: żywoty siedemnastowieczne 2008: XX.

10 Łowmiańska 1929: 77; Meilus 2001: 279.

11 See the case of Vilnius Cathedral Chapter in the16th - late18th c. where the yearly balance stayed near zero in almost all the years analysed: Jakulis 2014.

12 Sadowski 1964; Bogucka 1976; Mączak 1976.

13 Jachimowicz 1748.

${ }^{14}$ A 1764-65 census of the Vilnius kahal and its przykahals, LVIA SA 3726. 
Israel Klausner indicates that already in the early 17 th century there could have been about 2,500 Jews in Vilnius. ${ }^{15}$ Maria Cieśla, who dedicated a separate article to the issue of Jewish demographic trends in GDL, used a poll tax register from 1676-1677 to determine that at the time there were around 1,000 Jews in Vilnius: ${ }^{16} 922$ in the jurisdiction of the castle court (the initial Jewish quarter) and 83 in the jurydyka ${ }^{17}$ (a part of the city with its own legal jurisdiction) of the bishop. ${ }^{18}$ An additional source for calculating the Jewish population in the city are the podymne (based on housing) tax registers. An earlier 1667 podymne tax register indicates that Jews in Vilnius had paid taxes of 1,370 złotys on four big mural houses (wielkie kamienice), 14 smaller mural houses (małe kamienice) and 156 houses that could be identified as communal (z dymow pospolitych z Sasiadami), ${ }^{19}$ numbering 174 houses in total. The $1690 \mathrm{dym}$ register indicates 114 houses belonging to Jews at the time. ${ }^{20}$ Using the average inhabitance rate in the houses in Vilnius as determined by M. Cieśla, $9.4,{ }^{21}$ the size of the Jewish population in Vilnius in the second part of the 17th century according to dym registers could have been between 1,071 and 1,635.

It seems that the continuous process of population growth was hindered by the devastations of the early $1700 \mathrm{~s}^{22}$ However, there was continuous growth afterwards, and by the 1764-1765 census the Vilnius Jewish community had become the biggest in GDL, with 3,202 Jews in the city ${ }^{23}$ and an additional 295 Jews in the immediate suburbs of Antokoł and Śnipiszky (179 and 116 respectively ${ }^{24}$ ). This census, whose purpose was fiscal, that is to determine the number of Jews who had to pay a poll-tax (pogłówne), is considered to be much more accurate than the subsequent censuses at the end of the $1700 \mathrm{~s} .{ }^{25}$ The 1784 census indicated 4,980 Jews over one year of age, excluding community members from the Vilnius suburb of Antokot. ${ }^{26}$ As pointed out by J. Verbickiene, ${ }^{27}$ even though the number had grown from the 1765 census, we should have expected even higher growth during this period, as the overall results are inaccurate. This notion is confirmed by the 1788 census of houses in Vilnius. This census, relatively close to the one in

15 Cieśla 2015: 265.

16 Ibid: 263.

17 A question of the different jurydykas in the city still requires more attention and analysis. Lately, the best work on the topic has been done in the defended PhD thesis written by Kamil Frejlich: Frejlich 2017: $100-112$.

18 Wilnianie: żywoty siedemnastowieczne 2008: 313.

19 New podymne tax register from the year 1667, LVIA SA 3418, 1. 87.

${ }^{20}$ Metryka Litewska: rejestry podymnego Wielkiego Księstwa Litewskiego. Województwo wileńskie $1690 r .: 66$.

21 She used the same house register in 1690 that encompassed a list of houses in the streets that were predominantly inhabited by Jews to determine this, see Cieśla 2015: 253.

${ }^{22}$ Danute Blažytė claims that after 1710 there were between a few dozen and 450 Jews left. Blažytė 1999: 296.

${ }^{23}$ A 1764-65 census of the Vilnius kahal and its przykahals, LVIA SA 3726, 1. 27. Aggregated data was used from the project "Istorinès demografijos tyrimai ir jų taikymas Lietuvos Didžiosios Kunigaikštystès žydų surašymu pavyzdžiu." I thank Prof. Jurgita Verbickiene for allowing us to use the material before it is published in book form.

24 A 1764-65 census of the Vilnius kahal and its przykahals, LVIA SA 3726, 1. 47, 50.

25 Šiaučiūnaitè-Verbickienè 2015: 60-79.

${ }^{26}$ A 1784 census of Vilnius kahal, LVIA SA 3754.

27 Šiaučiūnaitè-Verbickienè 2015: 69-76. 
1784, indicates a Jewish population of $7,297,{ }^{28}$ while a letter by Vilnius kahal's creditor to the Four-Year Sejm in 1789 indicated a similar number of $8,000 .{ }^{29}$ While we lack the basis to investigate these numbers, ${ }^{30}$ we can assume that it was much closer the current reality than the 4,980 calculated in 1784 . Even though determining accurate population figures at different times in the 17th and 18th centuries still requires additional research, we can safely conclude that the Jewish population in Vilnius experienced significant growth in the 18th century. It also grew proportionally quicker than the overall population of the city. While in the mid- $1600 \mathrm{~s}^{31}$ it accounted for around $5 \%$ of the population, at the end of the $1700 \mathrm{~s}$ it was around $30 \% .^{32}$

The Jewish settlement in the city was initially located in a quarter that encompassed three streets: Żydowska (Jewish), Jatkowa (Meat Shop) and św. Mikołaja (St. Nicholas). ${ }^{33}$ It was based on the 1633 privilege that was granted to the community by King Władysław Vasa (1595-1648). The growth of the community in the 1700 s and the inability to limit the Jewish residence to the prescribed quarter was confirmed in the 1742 privilege that enabled Jews to settle in other streets as well. An exception was made for several urban arteries: one leading from the Gate of Dawn to the Cathedral, and the other from the Troki Gate to the Church of St. John. ${ }^{34}$ Jews in Vilnius were also quickly absorbed into the different suburbs of the city. We know that in the second half of the 1600s Jews settled in the city's private Radziwiłł jurydyka, most probably in Śnipiszky. ${ }^{35}$ Another suburban area settled by Jews was Antokoł, a part of which belonged to a magnate family, the Sapiehas. Jewish communities in these suburban areas eventually formed their own community administration bodies, called przykahals, ${ }^{36}$ that were attached to the main kahal in Vilnius. Furthermore, a large number of Jews belonging to the community (precisely 1,023) lived in the outskirts of the city. ${ }^{37}$ Most often they were attached to a karczma (inn).

According to the 1764-1765 census ${ }^{38}$ Jews in Vilnius were active in various economic occupations. They were artisans, leasers, various types of merchants (peddlers,

${ }_{28}$ Tabela dymow i ludności miasta stołecznego W[ielkiego] Ks[ięstwa] Lit[ewskiego] Wilna), MAB RS, F17-132, 1. 182 .

29 A representation of the position of Vilnius kahal creditors given as a response to a position provided by the elders of the kahal that were provided to the King and Sejm in 1789, in: Materiały do dziejów Sejmu Czteroletniego: 26.

30 The above-mentioned source only provides a sole number without any additional explanation.

31 It must be noted that just after the official establishment of the community in the city in 1633 .

32 If we use estimated figures that before the Deluge Vilnius was inhabited by around 20,000 people, out of whom around 1,000 were Jews, see: Paknys 2006: 18; Łowmiańska 1929: 71; Wilnianie: żywoty siedemnastowieczne 2008: XX; and if we use the 1788 house register in Vilnius figures that estimated the Vilnius population at 23,062 inhabitants, out of whom 7,297 were Jews: Glemža 2010: 35.

33 Šiaučiūnaitè-Verbickienė 2009: 136.

34 Ibid.: 141.

35 According to the 1697 register of income and expenses from Vilnius jurydyka belonging to Neuburg estates where there is a significant amount of taxes (488 $\mathrm{zl}$ and $19 \mathrm{gr}$ ) from the Jews in the jurydyka (paid together with the Tatars): AGAD, AR dz. XVIII, sygn. 287, p. 33. Furthermore, there are fragmented sources that Jews were living in Śnipiszky already in 1670s, as indicates a complaint from salt merchants in 1674 about Jews merchandising salt, herring, linen, wax, hemp, see: Akty cechów wileńskich, 1495-1759 2006: 382 (No. 383).

36 Šiaučiūnaitè-Verbickienè 2009: 145-146.

37 Information of the Jews living outside of the city but belonging to Vilnius kahal is provided in 1764-65 census of the Vilnius kahal and its przykahals, LVIA SA 3726, 1. 28-37.

${ }^{38}$ A 1764-1765 census from Vilnius kahal and its przykahals, in: LVIA SA 3726. 
storekeepers, bigger distributors, factors), and artists as well. It is difficult to establish a detailed occupation structure of the Jewish community, as only $50 \%$ of registered Jews in Vilnius had their professions noted in the census. This percentage was even lower in the suburban areas. The reason is simple - determining occupation was not the focus of the census, ${ }^{39}$ so it was not the primary issue to record. In addition to the main reason, we can also assume that those who did not have anything noted could either have engaged in multiple activities or were very mobile in changing them. Also, some of the 18 th century sources ${ }^{40}$ indicate a growing day-labour market, presupposing that at least a few Jews in the city were unspecified laborers working at day-to-day jobs. The overall majority of Jews who had their profession recorded in the census were craftsmen. Tailors (Pol. krawiec) and furriers (Pol. kuśnierz) accounted for 23\% and 20\% of the household population of those who had their occupations noted. Other important occupations were haberdashers (Pol. szmuklerz) - 7\%, tinsmiths (Pol. blacharz) - 4\%, cart drivers (Pol. furman) $-4 \%$, butchers (Pol. rzeźnik) - 4\%, goldsmiths (Pol. złotnik) - 4\%. Activities directly related to trade (stall-keepers, agents, cloth merchants) accounted for only $5 \%$ of the Jewish householders who had their occupations noted. However, it can be said that the artisans were most often the retailers of their own products. Suburban Jews deployed a similar structure of occupations. However, as a large portion of them were not tied to any type of activity, this statistic is rather misleading. A supporting cast of merchants was played in a way by Jews from the nearby inns. The 1784 census in general echoes similar occupational trends among community members, even though it had an even lower rate of noted professions. ${ }^{41}$

The occupational structure in Vilnius was significantly different from that of the smaller towns. ${ }^{42}$ One feature of the Vilnius Jews was a very high percentage of artisans, especially those making different kinds of apparel. Another was the high number of different specialties (28 if excluding the communal services). Unlike in smaller towns, especially private ones, the activities of Jews were much more actively regulated in Vilnius. ${ }^{43}$ Most often it was done by the urban Christian artisans' guilds ${ }^{44}$ for whom the Jewish artisans were longtime competitors. Besides the competitive nature of the other socio-economic groups, Jews had also to obey various communal regulations. Lithuanian Vaad provisions indicated ${ }^{45}$ that the community tried to control almost every economic activity, from leasing to money exchange, lending, trade, measuring instruments, forbidding forgery, and contracting goods for future assets. This situation

39 Its main aim was better taxation as detailed in the konstytucja "Pogłowne żydowskie W. X. Lit.": Volumina legum, Ab anno 1764 ad annum 1768, vol. 7 (1860): 81-83.

40 Such as income and expenses books of various socio-economic entities in the city like the Franciscans' friary in Vilnius: VUB RS F4-A3843 (1671-75), F4-A3822 (1759-62), F4-2958 (1790-1795).

41 Tamulynas 1999: 330-333.

42 While each specific case and town was different, M. Cieśla has briefly described the case of Słuck (a private Radziwiłł town in present-day Belarus): "Most of the Jews were involved in trade and the production of alcohol." Cieśla 2012: 569-570.

43 Šiaučiūnaitè-Verbickienė 2009: 152-175.

44 The constraints on the Jewish artisans set by their Christian counterparts in Vilnius were analysed in length by J. Verbickiene. They involved limiting clients, trade places, acquisition of the raw materials, integration of Jews into the Christian guilds and their subsequent control among other means, see: ŠiaučiūnaitėVerbickienè 2009: 152-175.

45 Michałowska-Mycielska 2016: 130-148. 
enabled a specific socio-economic landscape where Jews were hindered by the regulations and in a competitive environment had to find various partnerships and protections and operate in the city while living outside of it. ${ }^{46}$ The system and network of these relationships is a major focus of this article. They will be examined in the following segment.

\section{Jewish business networks: Partnerships and patronages}

A well-known feature of the Jewish population in the Polish-Lithuanian Commonwealth was its protection by the magnate families. ${ }^{47}$ This was especially evident in the private towns where members of the magnate families were the principle decision-makers. However, the political environment in the royal capital of Vilnius was different. Here, the power was shared between the city burghers, a voivode, and a bishop. The city was divided into several jurisdictions belonging not only to the above-mentioned entities, but also to the religious houses, several magnate families, and a castle supervisor. This complex environment aided the Jews, as they could bypass various restrictions issued by the Christian citizens through different legal frameworks.

A key partner for the Jews and the Jewish community in Vilnius was the voivode. Although we still lack in-depth legal analysis, it seems that this position was the guarantor of the Jewish autonomy and rights in the city as the main representative of the king. It appears so from the communication between the elders of the community and the voivodes. The questions raised in these letters ${ }^{48}$ vary from the protection in courts in specific cases, ${ }^{49}$ especially against the City Council of Vilnius ${ }^{50}$ to help relieve some of the debt. ${ }^{51}$ The latter issue intensified at the end of the 1700 s. It was a result of the difficult financial situation of the kahal, ${ }^{52}$ which the kahal's elders were trying to manage. For example, in 1787 they wrote to then Vilnius voivode Karol Stanisław Radziwiłł (1734-1790) complaining about the debt burden and asking for some relief. The elders were seeking the protekcja (protection) from the voivode against their creditors,

\footnotetext{
46 Jurgita Verbickienè argues that it was done successfully, see Šiaučiūnaitė-Verbickienė 2009: 175. A growing Jewish population in the city also confirms this notion.

47 See for example the works of Adam Teller and Moshe Rosman. Also Rosman 1991; Teller 2016; Bardach 1990.

48 We have used the letters from the kahal elders to the Radziwiłł family voivodes: AGAD, AR dz. V, sygn. 17445 (2nd part).

49 A 1779 letter from Vilnius kahal to Karol Stanisław Radziwiłt Panie Kochanku (1734-1790): AGAD, AR dz. V, sygn. 17445 (2nd part), 1. 39.

${ }^{50}$ A 1753 letter from Vilnius kahal elders to Michat Kazimierz Radziwitt "Rybeńko” (1702-1762): AGAD, AR dz. V, sygn. 17445 (2nd part), 1. 3.

${ }^{51}$ A 1787 letter from Vilnius kahal to Karol Stanisław Radziwitt Panie Kochanku (1734-1790): AGAD, AR dz. V, sygn. 17445 (2nd part), 1. 47-51; Several more letters written to Karol Stanisław Radziwiłł without the date: AGAD, AR dz. V, sygn. 17445 (2nd part), 1. 57, 63.

52 Vilnius kahal in the second part of the 18th c. was in arrears amounting almost 700,000 $\mathrm{zl}$ as per a 1766 debt liquidation report (A list of creditors from the Vilnius kahal account of income used to pay arrears and interest from 1767 to 1771: LVIA SA 3753) and several reports from the 1790s (Vilnius Jewish community's creditors' list and interest payments from the period of 1793 to 1799: LVIA SA 3763, 1. 3-4).
} 
especially the religious houses, to ease up conditions for repayments. In another letter ${ }^{53}$ they asked for partial default altogether, citing unbearable conditions where Jews were fleeing the city, while the ones who did not had no place to live and eat properly. It is unclear whether these requests were successful. However, we know that Radziwiłł family members responded and intervened in the community's matters. For example, Michat Kazimierz Radziwiłł (1702-1762) promised his protection in $1745 .{ }^{54}$ At the same time, he intervened into the Jewish community elections of the kahal, ordering to coordinate the candidates. ${ }^{55}$ Karol Stanisław Radziwiłł similarly intervened in the case between the community and its former rabbi Samuel Wigdorowicz ${ }^{56}$ (Samuel ben Avigdor ${ }^{57}$ ). The fact that such interventions were very similar to the ones in the private magnate towns ${ }^{58}$ shows how much the Vilnius kahal was attached to the position of the voivode and how important for the kahal was his power and protekcja.

One could argue that the elders of the kahal seeking protekcja might have written to the Radziwiłł family members, rather than to the institution and position of the voivode. Some of the magnates in the city were powerful enough, as they also owned a significant part of the city through their own jurydyka. Therefore, it could be argued that there was a thin line between the personal and institutional protekcja. However, the letters from the Jewish community were sent only when one or another Radziwiłł family member held the position of the voivode. Furthermore, the Jews were seeking protection from the other voivodes as well. For example, in 1717 the then-voivode of Vilnius, Kazimierz Jan Sapieha (1641-1720) noted that he had taken under his protection (in the source: wziat go $w$ protekcje $)^{59}$ a goldsmith, Aszor Izakowicz and asked the Vilnius religious houses that had various loan issues with him, the Christian goldsmiths' guild and the castle soldiers not to disturb his protegee in any way. It is important to notice that just three years earlier, in 1714 the same Jew had been found guilty, with Zacharius Izakowicz, by Vilnius podwojewoda Michał Rafał Szumski in accordance with a complaint of the city's goldsmiths that Izakowicz had engaged in illegal activity, created false products and therefore deceived the good Christians. ${ }^{60}$ Under the protection of Kazimierz Jan Sapieha, this Jew found a way to bypass the problem and continue to work in the fields that seemed to be profitable. ${ }^{61}$ These examples indicate how important the position of the voivode was for the Jewish community in Vilnius and individual Jews in general.

${ }^{53}$ A letter to Karol Stanisław Radziwitt (date unknown), in: AGAD, AR dz. V, sygn. 17445 (2nd part), 1. 63 .

54 The book of economic activities by Michat Kazimierz Radziwilt in 1745-1748: AGAD, AR dz. XXIX, sygn. 5: 1-3; Various documents related with the Vilnius kahal: AGAD, AR XVIII, sygn. $266:$ 8-10.

55 A 1762 order to Vilnius kahal by Michał Kazimierz Radziwiłł, in: The book of economic activities by Michat Kazimierz Radziwitt in 1761-1762: AGAD, AR dz. XXIX, sygn. 10, 1. 251-252

56 The book of economic activities by Karol Stanisław Radziwitt in 1783-1786: AGAD, AR dz. XXIX, sygn. 16: 189-190.

57 Cohen 2003: 107.

58 For example, see Rosman 1991: 185-204; Teller 2016: 53-58.

59 Akty cechów wileńskich, 1495-1759 2006: 19 (No. 532).

${ }^{60}$ Ibid.: 13-14 (No. 519).

${ }^{61}$ It is a recurring theme about which city's goldmisths' complained, as can be shown in another complaint by them, in: Akty cechów wileńskich, 1495-1759 2006: 23 (No. 543). 
Still, both the above-mentioned magnate families, the Radziwiłłs and the Sapiehas, were important partners for the Vilnius Jews, even without the held administrative positions in the district. This importance resulted in accommodating large number of Jews in their jurydykas just outside the city. The Radziwiłłs did this in Śnipiszky, a territory they acquired in 1623, ${ }^{62}$ while the Sapiehas did so in Antokol. As per the 1764-65 census there were 179 Jews over one year of age in the Sapieha's jurydyka, ${ }^{63}$ and 116 Jews in the Radziwiłłs' jurydyka. ${ }^{64}$ While the numbers do not seem very high, especially with the overall population size in the city at the time, it must be noted that these suburban areas had experienced rapid growth in the Jewish population, especially since the middle of the 18th century. For example, from 1737 when there were 12 Jewish houses registered ${ }^{65}$ in Śnipiszky, this number had risen to 38 in $1791 .{ }^{66}$ One of the reasons for this growth was that the Radziwiłls often employed an incentive package to encourage settlement in their domain. It was a tax-free period on rent called Stoboda. It could continue for several years until the family could make a living and then profit the treasury of the jurydyka's owner. While not always a specific time period for Stoboda is given in the sources, at least in 1737 the most common exemption from taxes lasted eight years. ${ }^{67}$ It must be noted that gradually throughout the 1700s a tax-free incentive on rent was decreasing. The number of rent contracts with Stoboda incentive in Śnipiszky in 1764 was smaller than in 1737, while there was no tax-free rent for the Jews in 1791 altogether. This suggests that the territory was nearing full settlement, and there was no need for its owners to encourage it further by losing part of their revenues. These jurydykas of the above-mentioned magnates provided not only a place to live, but also legal protection ${ }^{68}$ that was just as important as the living space.

While the magnates provided legal protection, accommodating space for the growing population, it does not seem that they supported the Jews financially. At least this is the case with the Vilnius kahal, which most often resorted to loans from the various religious houses. ${ }^{69}$ While the magnates did not engage in financial support of the Jewish communal body in Vilnius (they themselves were often on the receiving end of the credit issued by the religious houses ${ }^{70}$ ), they still conducted economic transactions, sometimes

${ }^{62}$ Krzystof II Radziwiłł (1585-1640) acquired it while exchanging lands with the Vilnius City Council as noted in the letters from Krzystoff II Radziwitt and Vilnius City Council to each other in 1623: AGAD, AR dz. XVIII, sygn. 38: 63-67.

${ }^{63}$ A 1764-65 census from Vilnius kahal and its przykahals: LVIA SA 3726: 45-47.

${ }^{64}$ A 1764-65 census from Vilnius kahal and its przykahals: LVIA SA 3726: 49-51.

${ }^{65}$ A tax register of the Radziwitt jurydyka in Vilnius in 1737: AGAD, AR Dz. XVIII, sygn. 270: 1-10.

${ }^{66}$ A tax register of the Radziwitt jurydyka in Vilnius in 1791: AGAD, AR Dz. XVIII, sygn. 270: $133-143$.

67 A tax register of the Radziwitt jurydyka in Vilnius in 1737: AGAD, AR Dz. XVIII, sygn. 270: 1-10.

${ }^{68}$ A 1739 instruction for the Jews, Tatars and peasants living in the jurydyka of the Radziwitts in the inventories of the jurydyka: AGAD, AR Dz. XVIII, sygn. 270: 32-34.

69 Out of the total arrears of the Vilnius kahal of 694,455 , as was calculated by the debt liquidation commission in 1767 , various religious houses constituted $96 \%$ of this amount. Jesuits were the largest creditors with 380,375 zł worth of credit alone, in: a list of creditors from the Vilnius kahal account of income used to pay arrears and interest from 1767 to 1771: LVIA SA 3753, 1. 3.

70 See, for example, records of the so-called capital tax that was enacted in 1776 and functioned in the years of 1777-1781 before being discarded. It taxed various form of credit above $1000 \mathrm{zl}$. The Sapiehas and the Radziwiłłs, at least in the area of the Vilnius voivodeship, were only the debtors: capital tax registries from the Vilnius voivodeship (propriae): LVIA SA 3698, 1. 491-495, 612-626 (year 1777); 1. 508-511, 556-576 (1778); 1. 525-529 (1779); 1. 546-551 (1780); 1. 552-555 (1781). 
quite large, with individual Jews. At least this is the case with the Radziwiłł family. They resorted to the individual Vilnius Jews for acquiring loans, ${ }^{71}$ buying goods, ${ }^{72}$ and leasing their property around Vilnius. ${ }^{73}$ However, as the nature of these sources (letters and contracts) are rather fragmentary, it is hard to evaluate the full extent of the contacts between the Vilnius Jews and the Radziwiłł family.

However, the smaller noble houses actively provided short-term loans to the Vilnius Jews, especially in the mid-1700s. Numerous bills of exchange contracts noted in the lay judges' books ${ }^{74}$ refer to Vilnius Jews, most often identified as city merchants, taking as much as 4,000 złotys worth of credit. In all of these cases the contracts stipulated the return of the loan in one year. Therefore, they were much different from the long-lasting credit contracts of the Vilnius kahal. Furthermore, it is interesting to note that while there were no provisions in these contracts about the interest rate or payments (even though it seems rather ambiguous ${ }^{75}$ ), there were very rather strict enforcement provisions. Most notably, if a Jew had not paid the due amount on the specified day, they would instead need to pay four times the original amount, or this amount would be recovered from their movable and immovable property. A key part of these loan contracts were the three guarantors. They were noblemen who were asked to do so by the debtors. ${ }^{76}$ It is unclear yet what kind of relationship these guarantors had with the debtors or creditors. Some

${ }^{71}$ For example, A bill of exchange from Janusz Radziwitt (1612-1655) to a Vilnius Jew Lewko Fayszewicz for 4730 zt: AGAD, AR dz. XXI, sygn. F 59; Letters and other documents about the debt issues of Vilnius Jew named Jakub Mojżeszowicz with the Radziwitt family members in 1659-1666: AGAD, AR dz. XXI, sygn. M 252; An agreement between Radziwitl steward Stanisław Niezabytowski and Vilnius Jew Dawid Lewkowicz about the debt settlement in 1671: AGAD, AR dz. XXI, sygn. L 120, p. 20; An assignation of the Radziwitt treasury in Stuck for the payment for the Eliasz bill of exchange on the January 6, 1763: AGAD, AR dz. XXI, sygn. E 26, p. 8.

72 A contract and a bill between Janusz Radziwitl and Dawid Lewkowicz about buying various fabrics for the army for 11,390 zt. and $6 \mathrm{gr}$. in 1653: AGAD, AR dz. XXI, sygn. L 120: 11; A settlement between Bogusław Radziwitt and Vilnius Jew Jakub Mojżeszowicz about outstanding debts incurred by his cousins Janusz Radziwitt for acquiring goods from the Jew's shop: AGAD, AR dz. XXI, sygn. M 252; Assignation by Michat Kazimierz Radziwitt to pay for the goods of Vilnius Jew merchant named Eliasz: AGAD, AR dz. XXI, sygn. E 26: 1-5.

73 We will analyse these cases in the next chapter, but that the Radziwiłl property (especially mills) around Vilnius was a popular choice of investment is showcased by a letter by two arendarze (leesees) from Vilnius: Jankiel Szlomowicz and Szymon Szemetulski, stating their upmost intentions ("[...] my zwłaśćiwey ochoty naszey [...]") in leasing a mill in a suburban district called Popławy.

${ }^{74}$ For example, in the years 1742-1744 alone there were at least 20 such credit contracts between the Vilnius Jews and various noblemen: LVIA SA 5348, 1. 171-172, 173-174, 175-176, 255-256, 344-345, 346-347, 382-384, 528-529, 530-531, 532-533, 534-535, 536-537, 557-558, 668-669, 752-753, 989-990, 1057-1058, 1065-1067, 1315-1316, 1337-1338. While the number is a bit lower in the other years (for example in the period of 1745-1747, there were 15 such contracts noted down in the lay judges' book, in: LVIA SA 5349, 1. 117-118, 119-120, 121-122, 123-124, 125-126, 365-366, 430-431, 432-433, 821-822, 825-826, 827-828, 873-874, 1166-1167, 1203-1204, 1296-1297. This clearly indicates a tendency, at least in the middle of the 18 th $\mathrm{c}$.

75 And most probably they had been agreed upon and noted in the original contract, out of which only the main part about the capital sum and repayments date were inscribed in the city books.

${ }^{76}$ As an example of the actual wording: "Podlug prawa proszony Pieczętarz od wyż pomienionych osób do tego obligu...," in the bill of exchanges contract in the year 1743 between the Jews Moyzesz Hirszowicz, Vilnius merchant, his wife Basia and their creditors Władyslow Ludwik Paraphianowicz and his wife Katarzyna for 250 thalers in the lay judges book from the years of 1742-1744: LVIA SA 5348, 1. $752-753$. 
of the figures appear in several bill-of-exchange contracts, ${ }^{77}$ suggesting that there might have been long-lasting trust between certain individuals and in general between these different socio-economic groups. This notion may be supported by the fact that often one nobleman would provide loans to several Jews at the same time. ${ }^{78}$

While Christian citizens, especially the artisans, were clearly the main competitors for the Jews in Vilnius, ${ }^{79}$ it did not mean that there were no contacts between these two socio-economic groups. It seems that out of all Vilnius citizens, Christian merchants were the principal partners for the Jews. Vilnius merchants such as Stefan Domański, ${ }^{80}$ Jan Pott, ${ }^{81}$ and Joachim Reyter, ${ }^{82}$ members of the city's political elite such as Henric Mones, ${ }^{83}$ Piotr Procewicz, ${ }^{84}$ and Eustachy Szperkowicz ${ }^{85}$ provided credit to Jews. For example, the counsellor Piotr Procewicz had a separate category in his inventory dedicated solely to loans issued to Jews. They amounted to a quite substantial figure in the

77 For example, one Tomasz Benedykt Kawecki, Vilnius podstarości, was the guarantor in the credit contracts by Moyzesz Hirszowicz in 1743 for 250 thalers (LVIA SA 5348, 1. 752-753), Lazar Salomonowicz, Chaya Salomoniwczowa and Michael Chaymowicz in 1743 for 30 thalers (LVIA SA 5348, 1. 668-669), Samuel Leyzarowicz, Basya Leybowiczowa, Leyzor Izakowicz, Hinda Jewnowiczowna, Jozef Irszowicz, Fruma Zelmanowiczówna in 1743 for 400 thalers (to pay the debt of Vilnius kahal) (LVIA SA 5348, 1. 557-558), Józef and Fruma, Hirszowiczs in 1742 for $1500 \mathrm{zl}$ (LVIA SA 5348, 1. 344-345).

78 This most often happened at the same time when a nobleman was in Vilnius to conduct his business. For example, on 10 April 1742 there were 3 loan contracts between Jan Monkiewicz, cześnik (a cup-bearer) of the Vilnius voivodeship and his wife Katarzyna with different Vilnius Jews, in the Lay judges book from the years of 1742-1744: LVIA SA 5348, 1. 171-172, 173-174, 175-176. Similarly, there were 5 contracts between Vilnius Jews and a Baron Ferdinand Towbie, putkownik (the colonel) of his majesty dated 18 October 1743: LVIA SA 5348, 1. 528-529, 530-531, 532-533, 534-535, 536-537. Another example is Józef Skalski, a treasurer of the Orsza powiat, who provided one 400 thaler loan to Vilnius Jews on 24 May 1743: LVIA SA 5348, 1. 557-558, and a 100 thaler loan on 14 February 1744: LVIA SA 5348, 1. 989-999. Vilnius merchant Stefan Domański had multiple loans with Jews in the early 1790s: one, 300 ducats bill of exchange to Leyba Gordon Rabinowicz agreed upon on 22 November 1790: LVIA SA 5354, 1. 260; another, to Jankiel Judelowicz for 220 ducats on 2 December 1790: LVIA SA 5354, 1. 264; and again to Leyba Gordon Rabinowicz for 500 ducats on 28 March 1791: LVIA SA 5354, 1. 338.

79 See for example the numerous complaints by the Christian artisans and the Jews, in: Akty cechów wileńskich 2006: 331 (No. 308), p. 339 (No. 315), p. 344 (No 323), p. 345 (No. 324), p. 368 (No. 357 ), p. 369 (No. 360), p. 371 (No. 367), p. 382 (No. 383), p. 411 (No. 417), pp. 412-413 (No. 418), pp. $412-413$ (No. 419), p. 417 (No. 426), p. 8 (No. 510), p. 9 (No. 511), p. 10 (No. 514), p. 13 (No. 517), pp. 13-14 (No. 519), p. 23 (No. 543), pp. 23-24 (No. 544), p. 24 (No. 545), p. 24 (No. 546), p. 26 (No. 548), pp. 26-27 (No. 549), pp. 28-29 (No. 554), p. 54 (No. 593), p. 76 (No. 627), p. 88 (No. 649), p. 108 (No. 694), p. 108 (No. 695$)$, pp. 131-132 (No. 717), p. 196 (No. 823), p. 196 (No. 824).

${ }^{80}$ As has been already shown in another reference point, Stefan Domański had several protested credit contracts in quick succession in the early 1790s. There might be even more payments that were not inscribed in the city council or lay judges' books.

${ }^{81}$ An inventory after the death of Vilnius merchant Jan Pott noted in the city council books of 1668-1672 (a specific date for the inventory is unknown): LVIA SA 5107, 1. 186-203.

${ }_{82}$ An inventory after the death of Vilnius merchant Joachim Reyter noted in the city council books of 1669-1674 (a specific date for the inventory is unknown): LVIA SA 5106, 1. 660-679.

${ }^{83}$ An inventory after the death of Vilnius burgomaster Henric Mones noted in the city council books of 1666-1668 (a specific date for the inventory is unknown): LVIA SA 5104, 1. 71-78.

${ }^{84}$ An inventory after the death of Vilnius consul Piotr Procewic noted in the city council books of 16711695 dated in March 18, 1676: LVIA SA 5111, 1. 1-20.

${ }^{85}$ An inventory after the death of Vilnius burgomaster Eustachy Szperkowicz noted in the city council books of 1671-1695 dated in 1685: LVIA SA 5111, 1. 644-657. 
late 1600s: 13,417 złotys and 11 groszy. ${ }^{86}$ It is difficult to establish any kind of pattern among these loans, but we can see that they were mostly either very small (probably a due amount for some unpaid wares) or middle-sized (most probably designated for economic activities of the Jews). It must be noted that the latter often were short term, sometimes obliging the Jews return the loan as soon as in one month, as was the case with Leyba Gordon Rabinowicz in $1791 .{ }^{87}$

Also, there were trade arrangements and contracts between the Jews and the Christian citizens. For example, a case from the beginning of the 18 th century ${ }^{88}$ shows a Jewish merchant from Vilnius, Jozef Heliaszewicz, acknowledging in 1709 a lasting debt of 1,000 tynf to Michał Raphał Szumsky, Vilnius podstoli and podwojewodzy, which he assumed in 1706 to conduct trading business in Königsberg. Jozef Heliaszewicz argued that he could not sell his wares due to the troubling political situation. Therefore, he agreed to sell his products to a local city citizen, merchant Michał Dembowsky on the promise that he would receive the final installment of the money several weeks later. Eventually, Jozef Heliaszewicz did not receive this payment; he apologized profusely to Michał Raphał Szumsky, and finally transferred his own obligations to Michał Dembowsky.

While these cases showcase the level of interaction between upper classes of both Christian and Jewish communities in the city, similar engagement occurred within the lower strata as well. These are well-described in the available court books of the Radziwiłł jurydyka in the years $1787-1791 .{ }^{89}$ Here we can find a case like a Jew buying a brick-yard from a Christian and then allowing the latter to use it until the last payment is made; ${ }^{90}$ a sales contract for the inn with the bakery that was built by a Christian family named Matuszewicz and eventually sold to the Jewish family of Josiel and Rosia Leyzerowicz who then resold the same premises just a year later to a family of Vilnius artisans. ${ }^{91}$ Of course, the most numerous were the simple sale contracts of houses in the jurydyka, where Jews were active both in selling and acquiring property to and from Christian residents. ${ }^{92}$

${ }^{86}$ An inventory after the death of Vilnius consul Piotr Procewicz noted in the city council books of 1671-1695 dated in March 18, 1676: LVIA SA 5111, 1. 4.

87 A wexel from Leyba Gordon Rabinowicz for 500 ducats in March 28, 1791: LVIA SA 5354, 1. 338.

${ }^{88}$ LVIA SA 5122, 1. 305-306.

89 Radziwitt jurydyka court books of 1787-1791: AR dz. XVIII, sygn. 260.

${ }_{90}$ A contract between Israel Muwszowicz and Gregorz Misiewicz for buying a brick yard for $100 \mathrm{zl}$. in 1787: AGAD, AR dz. XVIII, sygn. 260: 52.

${ }_{91}$ A 1791 sales contract for the bakery that was located in the surroundings of the Szeskine hill nearby Meyszagolski guest house for 215 zt.: AGAD, AR dz. XVIII, sygn. 260: 382; A 1792 sales contract for the same inn with the bakery between Josiel and Rosia Leyzerowiczs on the one side and Vilnius artisans Jakub and Leonone Hertmans for $270 \mathrm{zt}$ : AGAD, AR dz. XVIII, sygn. 260: 398-401.

${ }_{92}$ A sales contract for part of the house behind the Tatar gate for 540 zt. between Ewa Juchnowiczowa and Szmuyl together with his wife Lei Ickowicz in 1787: AGAD, AR dz. XVIII, sygn. 260: 104-107; A sales contract for the house for $200 \mathrm{zt}$. between Michat and Wiktorya Kusminckis on the one side and Jankiel and Jorze Beniamowiczs on the other: AGAD, AR dz. XVIII, sygn. 260: 113; A sales contract for the house in Śnipiszky for $1550 \mathrm{zt}$. in 1787 between Jozef and Anna Gintowiczs on the one side and Abraham and Feydzie Jankielwiczs from the other: AGAD, AR dz. XVIII, sygn. 260: 134-136; A sales contract for the mural house on the way to the Green Bridge for $3.500 \mathrm{zt}$. between Azik and Gitel Berkowiczs on the one side and Andrzej together with Marciannie Kurcyws on the other: AGAD, AR dz. XVIII, sygn. 260: 144-145; A 1788 sales contract for a small house in Śnipiszky between Hinda Berkowiczowa and Kazimierz Kazanowski for 80 zt.: 
To sum up, although the Jews in Vilnius clearly competed with the Christian citizens, especially in the area of craftsmanship, they also often forged partnerships with Christians. Still, when the Jews were in risk of losing their assets, opportunities to work, and ways to conduct their economic activities, they often looked for the protection and support of the main magnate families of the Grand Duchy. This support was showcased through service contracts, settlement policy in the magnates' jurydykas in the city, and legal protection. The last was the focus of the Jewish community when addressing the local voivode, who was a very important partner for Vilnius Jews. Magnates were not financial donors to the community and its members, but other lesser noble families often were.

\section{In and around the city: Jews in the hinterland of Vilnius}

As already mentioned, the Jews were quickly absorbed in the immediate Vilnius suburbs such as Śnipiszky and Antokoł, among others. However, the Jews' economic activities were not limited to the immediate suburbs as the economic hinterland of the city encompassed a larger territory. In the following part we will analyse several cases of how Jews employed various economic structures, partnerships that enabled them to be an important part of city's economic hinterland while being based slightly outside of the city. We will mainly focus on such economic entities as inns and mills, as they played a key part in the economic landscape of GDL..$^{93}$

One of the principal complaints from the Christian artisans towards the Jewish community in Vilnius was that Jewish butchers were illegally buying and brining cattle not only in their quarters, but also in other places in the city, its suburbs and the countryside beyond. ${ }^{94}$ They were accused of using Jewish subordinates ${ }^{95}$ to facilitate this. While it is not entirely clear who these subordinates were, we can assume that they were fellow Jews from suburbs or taverns who were closer to the cattle ranches, and therefore could help to accommodate the transaction. This brings us to the importance of taverns in the city's economic hinterland. As we can see from another complaint ${ }^{96}$ in the 1700 s, Jews were accused of using a tavern in Kojran (some $10 \mathrm{~km}$ outside Vilnius) for allegedly illegally taking hides from the city and processing them there. The same issue came up again a year later in the same place. This court case alleged that the Vilnius hide butchers (zarębaczy), in partnership with Jews named Icko (a lessee of the Kojran tavern) and Hyrsz (an inhabitant of the Śnipiszky suburb), used the Kojran tavern for storing illegally

AGAD, AR dz. XVIII, sygn. 260: 178-179; A 1788 sales contract for a house with a brewery that was nearby the mill of the voivode between Leyba Szmuylowiczowa and Jakub Jakułdowicz for 1600 zt.: AGAD, AR dz. XVIII, sygn. 260: 180-181; A sales contract for the house belonging to the same Leyba Szmuylowiczowa that she sold for $1400 \mathrm{z}$. to Krzystoff Sienkiewicz in 1789: AGAD, AR dz. XVIII, sygn. 260: 180-181.

93 See for example the case of the inns as provided elegantly by Glenn Dynner. Altough his focus is on the 19th c., the economic structures were not that different in the 17th and 18th c. Polish-Lithuanian Commonwealth, in: Dynner 2015.

94 Akty cechów wileńskich 2006: 23-25 (No. 544, 546, 547).

95 "[...] zajeżdżając w pole przez subordynowanych przekupują [...]": Akty cechów wileńskich 2006: 25 (No. 547).

${ }_{96}$ A complaint by the guild of butchers in January 8, 1720: Akty cechów wileńskich 2006: 31 (No. 561). 
bought hides. ${ }^{97}$ Here, together with its lessee they merchandised production, thus bypassing requirements to conduct such business in the city. This and other cases ${ }^{98}$ show not only how Jews became partners of a Christian guild competing against another, but also the importance of taverns in bypassing strict controls that the Christian guild artisans tried to implement. Another important aspect is that these leaseholders often engaged in multiple activities, such as merchandising various goods. For example, another arendarz of a tavern in Dawgierdiszki (some $40 \mathrm{~km}$ from Vilnius) took fish to the city for the purpose of selling it, albeit unsuccessfully as he and his companion were beaten by local fishermen. ${ }^{99}$

First, it must be mentioned that Jews occupied a very large number of nearby Vilnius taverns, as indicated by their $1764-65$ census. ${ }^{100}$ These taverns were not only a place to stay and drink, ${ }^{101}$ but they also served a larger economic function, as important outposts for travelling merchants, storing goods, exchanging news and conducting monetary functions, among others. ${ }^{102}$ In the immediate vicinity of the city ${ }^{103}$ there were 38 taverns inhabited by 294 Jews $^{104}$ with an additional number of taverns beyond the immediate area. ${ }^{105}$ While we still lack sources on the economic daily life in the taverns, it seems that they were important structures not only at their own locations, but they were also strongly connected with Vilnius. One indicator is that the Jews living in Vilnius looked for opportunities to lease taverns around Vilnius and did so in places such as Kojran, ${ }^{106}$

97 Akty cechów wileńskich 2006: 42 (No. 574).

98 A similar situation occurred in 1722 when a guild of tanners complained that an arendarz of the same Kojran tavern illegally bought hides which were then resold: Akty cechów wileńskich 2006: 52-53 (No. 586). To add to that a nobleman Franciszk Białłozor, podkomorzy of Wiłkomierz, in the same year issued a claim to the same guild of tanners in Vilnius, because Kojran Jews had a hide belonging to him: Akty cechów wileńskich 2006: 52 (No. 587). Also: Akty cechów wileńskich 2006: 62 (No. 605).

99 A complaint by Jan Wialbut, mostowniczy of Oszmiań in 1758: Akty cechów wileńskich 2006: 198 (No. 830)

100 As per census of the Vilnius kahal and its przykahals conducted in 1764-65: LVIA SA 3726, 1. 1-64.

101 Dynner 2015: 82-130.

102 Ibid.: 1.

103 The territory of the economic hinterland of the city varied greatly. As notes urban historian Peter Clark: "In areas with a dense network of urban markets the trading hinterland might be quite localized, within walking distance - up to 10 kilometers. In less urbanized regions, the marketing zone could be much more extensive: in late medieval Hungary, for instance, market towns were often situated about 30 kilometers apart. Larger cities, with the major provisioning needs, depended on wide marketing zones." Later in the book he calls this wider region in a radius of 45 kilometers (Capital Cities and Their Hinterlands in Early Modern Europe 1996: 45, 140). While there should be more research on this in the economic system of the Polish-Lithuanian Commonwealth, for the purpose of the analyses of taverns we will use a $20 \mathrm{~km}$ radius, as a one-day walking distance.

104 The following taverns (karczmy) were included in this list: Ponarach, Sołomiance, Kiełmej, Kropinnicy, nad murowanym mostem w Dobrach Wace, Rokanciszkach, Kojranach, Wierzbach, Gozdikach, Mickunac, Rudominie, Niemieży, Niemież, Sołomianska, Gudetki, Smolanka, Rokujony, Orklany, Gudele, Sojdzie, Łojcie, nowa pod Wilnem, Podziekaniszki, Giedwidzie, Pustołowka, Szylany, Zwierzyniec, 7 karczmie in Antokot and Śnipiszky, Jurkiszki, 3 karczmie in Vilnius as per 1764-1765 census from Vilnius kahal and its przykahals: LVIA SA 3726, 1. 24-25, 28-37, 48-50, 57-58, 62-64. To determine specific locations all volumes of Stownik geograficzny Królestwa Polskiego i innych krajów słowiańskich were used.

105 The total number of all the taverns attached to the Vilnius kahal was 138 with 1218 Jews older than 1 year per 1764-1765 census from Vilnius kahal and its przykahals: LVIA SA 3726, 1. 24-25, 28-37, 48-50, 57-58, 62-64.

106 A tavern was managed by a Jew named Icko in the early 1720s.: Akty cechów wileńskich 2006: 42 (No. 574). Then in 1722 it is known that it already belonged as a lease to a Vilnius Jew, Izaak Izaakowicz: Akty cechów wileńskich 2006: 51 (No. 586). 
Niemież $\dot{z}^{107}$ ( $8 \mathrm{~km}$ away) and most probably many others. The leaseholders of these taverns engaged in multiple activities, as was shown in the previously mentioned cases. A network developed by Jews played a key part, one to their advantage in getting necessary provisions, providing storage facilities, conducting merchandising activities, and so forth.

Another important economic entity in the Polish-Lithuanian Commonwealth was the mill. There are so far no direct studies on the number of mills in Vilnius and its hinterland. Georg Max von Fürstenhoff, who drew up a city map in around the 1730s identified that there were at least six mills in Vilnius (the king's, the bishop's, and the voivode's, plus several paper mills and one identified as Weisgerber Walen). ${ }^{108}$ A list of taxes for the army (kwatergielt), most probably compiled around 1785-90, mentions three such mills in the suburbs in total, although only one in the city proper. ${ }^{109}$ It is difficult to determine the accurate number of mills in the larger hinterland area of Vilnius, as one would need to look at different inventories from different landowners. A 1764-65 census of the Jewish population in the Vilnius area indicates that the management of mills by Jews was much less frequent than that of the taverns. We find only two mills that were managed and inhabited ${ }^{110}$ by Jewish families at the time. However, we can also assume that there were a greater number of mills most probably managed by Jews who had their residences attached to a different place, like a tavern. For example, a so-called voivode's mill owned in 1780s by the Radziwiłł in the Vilnius suburb of Popławy was leased by a Vilnius Jew at the time. ${ }^{111}$ Another mill owned by the Radziwiłł family was located on the other side of the Wilia River in the suburb district of Zwierzyniec. ${ }^{112}$ While we can presume that it was also managed by local Jews, we do not have any sources to confirm this.

As the information on the ownership and management of mills in and around Vilnius by Jews is limited, we are unable to evaluate the full extent of the Jewish involvement in their management and connections with the economic life of Vilnius. However, we can clearly say that Jews played an ever-important part by leasing taverns near Vilnius. Here they not only performed the local function of producing and distributing alcohol and providing accommodation to travelers, but they also were and integral part of the larger

107 Vilnius Jew Wolff Aronowicz was a frequent lessee of the tavern in 1780s. Rent (arenda) contract for the tavern and the mill in Popławy (suburb of Vilnius) on 10 March 1782 noted in the book of economic activities of Karol Stanisław Radziwill II in 1780-1783: AGAD, AR dz. XXIX, sygn. 15: 280. Also, the same Jew got the contract for the mill in 1784. The book of economic activities of Karol Stanisław Radziwill II in 1783-1786: AGAD, AR dz. XXIX, sygn. 16: 70-71.

108 Ligusz 1996: 88-89.

109 Tabela dymow i ludności miasta stołecznego W[ielkiego] Ks[ięstwa] Lit[ewskiego] Wilna): MAB RS F17-132, 1. 184.

110 The mills were located in Dobrach Wace (13 km away from the city) and Wierzbach (19 km), as noted in The 1764-1765 census from Vilnius kahal and its przykahals: LVIA SA 3726: 28-29. Most probable explanation of the census logic in ascribing the living area to the mill, that it also possessed some kind of living quarters or some form of housing just beside it.

111 The book of economic activities of Karol Stanisław Radziwill II in 1780-1783. Rent (arenda) contract for the tavern and the mill in Popławy (suburb of Vilnius) from 10 March 1782: AGAD, AR dz. XXIX, sygn. 15: 280. Also, the same Jew got the contract for the mill in 1784. The book of economic activities of Karol Stanistaw Radziwill II in 1783-1786: AGAD, AR dz. XXIX, sygn. 16: 70-71.

112 Inventories of the Radziwitt family jurydyka in Vilnius in the 18th c: AGAD AR Dz. XVIII, sygn. 270: 25, 130 . 
Vilnius economic area, by helping to bypass city regulations, provide storage facilities, serve as a place of merchandising, and provide the city with provisions from the rural areas.

\section{Conclusions}

(1) The Jewish population experienced significant growth from the second part of the 17 th until the 18 th century after the official establishment of the community in 1633. Its share in the city's overall population had risen from around 5\% in the middle of the 17 th century to around $30 \%$ at the end of the 18 th.

(2) An analysis of the 1764-65 census shows that most of the Jews in Vilnius at the time were artisans. The dominant occupations among them were associated with making apparel. A 1764-65 census indicates a strikingly small number of Jews engaged in trade activities, even though they appear quite often in various economic sources. More than 50\% the Jews in both Vilnius and its suburbs did not have an occupation attached to them, possibly identifying either a lack of economic identity, a multi-occupational structure or the formation of a freeflowing labor market. To add to that, it must be noted that attributing occupation to the Jews was not the principal focus of the census, which also helps to explain the lack of noted economic activities among the Jews living in Vilnius.

(3) The strongest economic partnerships by the Vilnius Jews were forged with the magnates granting their protekcja, settlement opportunities, and economic contracts. Special attention was paid to the Vilnius voivode, who played a key part in ensuring legal protekcja and the level of autonomy for the Jewish community in the city.

(4) The houses of lesser noblemen often supported the Jewish merchants with the necessary capital. The religious houses also played a key part in providing necessary capital to the Vilnius Jewish kahal.

(5) While there was much litigation between the Jews and the Christian city-citizens (especially in the area of directly competing crafts), the competitive nature of their relationship seems to be exaggerated, as historians tend to rely on the normative and legal sources. Economic management documents indicate that Jewish and Christian city-citizens conducted economic and financial agreements, even though such contracts were not very frequent. The strongest relationship was between the Christian and Jewish merchants, but we also must add that there were guilds that incorporated both Christian and Jewish artisans.

(6) Suburban Jews played a key part in trade, especially in connecting Vilnius to its hinterland: by bringing necessary raw materials, acting as sales points in inns, and performing the function of intermediaries. Taverns comprised a very important economic entity for the connections within the economic area. There were 38 taverns managed by Jews in the $20 \mathrm{~km}$ radius around the city.

(7) The economic management documents analysed suggest that the competitive nature of the Jewish economic life in Vilnius in the 17th and 18th centuries, as argued by some scholars, is a bit exaggerated. While competition naturally 
existed, it co-existed with a formation of various partnerships, alliances, patronages, and usage of suburban links. The ability to work with different socio-economic groups was important for the substantial growth of the Jewish community in Vilnius during this period, also suggesting that Jews found good economic prospects in the city.

\section{BIBLIOGRAPHY}

\section{Sources}

a. Unpublished

LVIA - Lietuvos valstybės istorijos archyvas (Vilnius, Lithuania).

AGAD - Archiwum Główne Akt Dawnych (Warsaw, Poland).

VUB - Vilniaus universiteto bibliotekos archyvas (Vilnius, Lithuania).

MAB - Mokslų akademijos bibliotekos archyvas (Vilnius, Lithuania).

b. Published

Akty cechów wileńskich 1495-1759 (2006), ed. H. Łowmiański, Poznań.

Materiały do dziejów Sejmu Czteroletniego, vol. 4 (1969), A. Eisenbach, J. Michalski, E. Rostworowski, J. Woliński (eds.), Wrocław.

Metryka Litewska: rejestry podymnego Wielkiego Księstwa Litewskiego. Wojewodztwo wilenskie 1690 r. (1989), ed. A. Rachuba, Warszawa.

Słownik geograficzny Królestwa Polskiego i innych krajów słowiańskich, (1880-1902: 15 volumes).

Volumina legum, Ab anno 1764 ad annum 1768, vol. 7 (1860), ed. J. Ohryzka, Petersburg.

Wilnianie: żywoty siedemnastowieczne (2008), ed. D. Frick, Warszawa.

\section{Primary literature}

Bardach, J. (1990), Żydzi w Birżach radziwiłłowskich w XVII-XVIII wieku, Przeglad Historyczny, 90 (1-2): 199-220.

Blažytė, D. (1999), Vilniaus magistratas ir žydų bendruomenė XVIII a., in: Lempertas I. (ed.), Vilniaus Gaonas ir žydu kultūros keliai. Tarptautinès mokslinès konferencijos medžiaga, Vilnius: 293-299.

Bogucka, M. (1976), Kryzys monetarny XVII w.: konsekwencje społeczne i psychologiczne w Polsce, Roczniki Dziejów Spolecznych i Gospodarczych, 37: 87-102.

Capital Cities and Their Hinterlands in Early Modern Europe (1996), Clark, P., Lepetit, B. (eds.), Aldershot, Brookfield.

Cieśla, M. (2005), Łazarz Mojżeszowicz - przykład żydowskiej kariery w Wielkim Księstwie Litewskim, Kwartalnik Historyczny, 4: 5-29.

Cieśla, M. (2012), Between Religious Law and Practise. The Role of Jewish communities in the Development of Town's economy in the Grand Duchy of Lithuania in the 17th and 18th Centuries, Religion and Religious Institutions in the European Economy. 1000-1800, Firenze: 563-574.

Cieśla, M. (2013), Mojżeszowicz, Gordon, Ickowicz. The Jewish Economic Elites in the Grand Duchy of Lithuania 17-18th Century, Acta Poloniae Historica, 107: 101-127.

Cieśla, M. (2015), Liczebność Żydów w Wielkim Księstwie Litewskim w XVII w., Kwartalnik Historyczny, 122 (2): 243-268.

Cohen, I. (2003), Vilna (Jewish Communities), Philadelphia and Jerusalem.

Dynner, G. (2015), Yankel's Tavern: Jews, Liquor, and Life in the Kingdom of Poland, New York.

Frejlich, K. (2017), Horodnictwo wileńskie i jego jurydyka w XVII wieku, [rozprawa doktorska], Warszawa.

Frick, D.A. (2013), Kith, kin, and neighbors: communities and confessions in seventeenth-century Wilno, Ithaca [N.Y.]. 
Glemža, L. (2010), Lietuvos Didžiosios Kunigaikštystès miestu sajūdis 1789-1792 metais: monografi$j a$, Kaunas.

Hundert, G.D. (2006), Lenkijos ir Lietuvos žydai aštuonioliktame amžiuje: naujuju laiku genealogija, Vilnius.

Jachimowicz, B.B. (1748), Relacya o straszliwym upadku stolecznego miasta wilenskiego [...], Wilno.

Jakulis, M. (2014), Vilniaus katedros kapitulos pajamos XVI a. antroje pusėje-XVIII a. pajamų-išlaidų registrų duomenimis, Istorijos šaltiniu tyrimai, 5: 171-194.

Klausner, I. (1938), תולזות הקהל העברית בוילנה הלק רישון [Dzieje gminy żydowskiej w Wilnie], cz. 1, Wilno.

Ligusz, J. (1996), Plan Wilna Georga Maxa von Fürstenhoffa jako źródło historyczne, in: Kartografia wojskowa krajów strefy bałtyckiej XVI-XX w.: materiaty konferencji naukowej, Toruń, 20-22 października 1994 r., S. Alexandrowicz, Z. Karpus, W. Rezmer (eds.), Toruń: 73-92.

Łowmiańska, M. (1929), Wilno przed najazdem moskiewskim 1655 roku, Wilno.

Maciulevičius, A. (2015), The Socioeconomic and Demographic Patterns of the 17-18th Century Jewish Population in the Grand Duchy of Lithuania, Kwartalnik Historii Żydów, 254 (2): 203-230.

Mączak, A. (1976), Pieniądz i społeczeństwo w Rzeczypospolitej XVI-XVII w., Roczniki Dziejów Społecznych i Gospodarczych 37: 63-85.

Meilus, E. (2001), Rusų okupacinė valdžia Vilniuje 1655-1661 m., Lietuva ir jos kaimynai: nuo normanu iki Napoleono: Prof. Broniaus Dundulio atminimui, sud. Irena Valikonytė et al. Vilnius: 278-295.

Michałowska-Mycielska, A. (2016), The Council of Lithuanian Jews 1623-1764, Warszawa.

Nadav, M. (2008), The Jews of Pinsk, 1506 to 1880, Stanford.

Paknys, M. (2006), Vilniaus miestas ir miestiečiai 1636 m.: namai, gyventojai, svečiai, Vilnius.

Rosman, M.J. (1991), The Lords'Jews: Magnate-Jewish Relations in the Polish-Lithuanian Commonwealth During the Eighteenth Century, Cambridge.

Sadowski, Z. (1964), Pieniadz a początki upadku Rzeczypospolitej w XVII wieku, Warszawa.

Šiaučiūnaitè-Verbickienè, J. (2009), Žydai Lietuvos Didžiosios Kunigaikštystès visuomenèje: sambūvio aspektai, Vilnius.

Šiaučiūnaitè-Verbickienè, J. (2015), XVIII a. Lietuvos Didžiosios Kunigaikstystės žydų surašymai: jų patikimumas ir duomenų interpretavimo klausimai, in: Kintančios Lietuvos Visuomenè: struktūros, veikejai, idejos, Vilnius: 60-79.

Tamulynas, A. (1999), Demografinè ir socialinė profesinė Vilniaus žydų bendruomenès, in: Vilniaus Gaonas ir žydų kultūros keliai. Tarptautinès mokslinès konferencijos medžiaga, Vilnius: 316-336.

Teller, A. (2014), Culture and Money: The Economic Dimension of Cultural History and What It Can Teach Us, Jewish Quarterly Review 104 (2): 278-287.

Teller, A. (2016), Money, Power, and Influence in Eighteenth-Century Lithuania: The Jews on the Radziwitt Estates, Stanford.

Бершадский, С.А. (1881), Очерк истории виленской еврейской общины (1593-1793 г2.), Восход, no 7.

Бершадский, С.А.(1883), Литовские евреи: история их юридического и общественного положения в Литве от Витовта до Люблинской унии, 1388-1569 г., Петербург.

Бершадский, С.А. (1886), История виленской еврейской общины (1593-1649), Восход, по 10, 11. 